\title{
Drinking from Olivia Pope's Wine Glass: Fan Communities and the Impact of Parasocial Relationships on Consumption Behaviors
}

\author{
Morgan M. Bryant \\ Belmont University \\ Janée Burkhalter \\ St. Joseph's University \\ Natalie Wood \\ St. Joseph's University
}

This paper was presented at the 2019 International Summit of the

Music \& Entertainment Industry Educators Association

March 21-23, 2019

https://doi.org/10.25101/19.15

\section{Abstract \\ When I reach my Olivia Pope status I'm going to buy giant wine glasses to celebrate \#Scandal \#Ol- iviaPope \#Bosslady}

Product placement, often referred to as brand placement, is an orchestrated product message designed to influence audiences through the unobtrusive inclusion of a branded product in entertainment content (Balasubramanian 1994, 31). Orchestration may take various forms ranging from loaning the product to charging a fee. As a type of hybrid message (Balasubramanian 1994), product placements benefit from their non-commercial character due to the lack of sponsor identification. Interestingly, products may appear prominently whether or not an agreement is in place. For example, Hershey's Reese's Pieces candy was notably integrated into the plot of the film E.T. the Extra-Terrestrial playing a key role in E.T. finding his way home (Babin and Carder 1996). Similarly, Polaroid was repeated in the hook of Outkast's hit song "Hey Ya!" and used in the accompanying music video (Thompson 2004). Despite their mutual prominence, unlike Hershey's, Polaroid did not orchestrate or pay for its inclusion. In both cases, however, the brands saw increased sales and awareness.

Unbranded products such as haircuts (Russell and Puto 1999), dogs (https://www.independent.co.uk/arts-entertainment/tv/news/game-of-thrones-direwolves-huskies-animal-shelters-peter-dinklage-tyrion-lannister-a 7894821. html) and food (https://www.esquire.com/food-drink/food/ a13972/avengers-boosts-shawarma-sales-8707403/) have also seen increased sales following prominent placements. So, despite a lack of formal agreement or brand identifiers, unbranded products that are prominently featured within entertainment content may be sought out and adopted by consumers. This adoption may be facilitated by the existence of parasocial relationships - the long-term, intimate connections viewers build with media figures (Russell and Stern 2006).

The current paper investigates consumers' journey to identify and ultimately purchase an unbranded productthe Camille 23-oz. wine glass - used by Olivia Pope, the lead character of the political television drama Scandal. This particular journey originates in social media and culminates on the brand's web site. Social media's influence in consumer behavior has been investigated regarding television viewing habits, consumer decision-making, and the closely-related concepts of ratings and reviews (Bronner and de Hoog 2014; Dellarocas 2006; Hennig-Thurau et al. 2004; Kaplan and Haenlein 2010). More recently, scholars have investigated the role of social media in the consumer journey from problem recognition to post-purchase evaluation via the social commerce literature stream (Zhang and Benyoucef 2016; Kang et al. 2013; Yadav et al. 2013). However, to our knowledge no study to date has explored how consumers utilize Twitter to draw attention to and identify an unbranded product, generating significant interest and desire to drive online sales. In an effort to address this void we adopt a grounded theory approach, using the Camille wine glass as a case study. Adapting Yadav's stages of consumer journey, we highlight the interconnectivity and progression of consumers' conversations from Twitter to the 
Crate \& Barrel web site - examining the decision-making process across multiple platforms. We begin by examining the role and placement of the unbranded product in the television show, how consumers turn to social media and virtual fan communities to determine the identity of the product and their transition to the retailer website to make the purchase. We also explore when, where, and how product evaluations are shared with others to drive additional sales, identify those participants who played an instrumental role in the consumer journey as well as the content and format of messaging that appears to exert the most influence. We conclude with managerial recommendations.

\section{References}

Babin, L. A., and S. T. Carder. 1996. "Advertising via the Box Office: Is Product Placement Effective?" Journal of Promotion Management 3, no. 1,2: 31. https://doi. org/10.1300/J057v03n01 03 .

Babin, L. A., and S. T. Carder. 1996. "Viewers' Recognition of Brands Placed Within a Film." International Journal of Advertising 15, no. 2: 140-151. https://doi. org/10.1080/02650487.1996.11104643.

Balasubramanian, S. K. 1994. "Beyond Advertising and Publicity: Hybrid Messages and Public Policy Issues." Journal of Advertising 23, no. 4: 29-46. https://doi.org/ 10.1080/00913367.1943.10673457.

Bronner, F., and R. de Hoog. 2014. "Social Media and Consumer Choice." International Journal of Market Research 56, no. 1: 51-71. https://doi.org/10.2501/ IJMR-2013-053.

Dellarocas, C. 2006. "Strategic Manipulation of Internet Opinion Forums: Implications for Consumers and Firms." Management Science 52, no. 10: 1577-1593. https://doi.org/10.1287/mnsc.1060.0567.

Hennig-Thurau, T., C. Wiertz, and F. Feldhaus. 2015. "Does Twitter matter? The Impact of Microblogging Word of Mouth on Consumers' Adoption of New Movies." Journal of the Academy of Marketing Science 43, no. 3: 375-394. https://doi.org/10.1007/ s11747-014-0388-3.

Kang, J-Y. M., and K. K. Johnson. 2013. "How Does Social Commerce Work for Apparel Shopping? Apparel Social E-Shopping with Social Network Storefronts.' Journal of Customer Behaviour 12, no. 1: 53-72. https://doi.org/10.1362/147539213X13645550618524.

Kaplan, A. M., and M. Haenlein. 2010. "Users of The World, Unite! The Challenges and Opportunities of Social Media." Business Horizons 53, no. 1: 59-68. https://doi.org/10.1016/j.bushor.2009.09.003.

Russell, C. A., and C. P. Puto. 1999. "Rethinking Television Audience Measures: An Exploration into the Construct of Audience Connectedness." Marketing Letters 10, no. 4: 393-407. https://doi. org/10.1023/A:1008170406363.

Russell, C. A., and B. B. Stern. 2006. "Consumers, Characters, and Products: A Balance Model of Sitcom Product Placement Effects." Journal of Advertising 35, no. 1: 7-21. https://doi.org/10.2753/JOA00913367350101 .

Yadav, M. S., K. de Valck, T. Hennig-Thurau, D. L. Hoffman, and M. Spann. 2013. "Social Commerce: A Contingency Framework for Assessing Marketing Potential." Journal of Interactive Marketing 27, no. 4: 311- 323. https://doi.org/10.1016/j.intmar.2013.09.001. Zhang, K. Z., and M. Benyoucef. 2016. "Consumer Behavior in Social Commerce: A Literature Review." Decision Support Systems 86: 95-108. https://doi. org/10.1016/j.dss.2016.04.001.

Morgan M. Bryant is a recent graduate of the University of Georgia with a Ph.D. in Consumer Economics. She currently serves as a Faculty Fellow in the Curb College of Entertainment \& Music Business at Belmont University. In this capacity, Dr. Bryant teaches Entertainment Economics and a newly developed Social Media Analytics course. Her research focuses on social commerce, at the intersection of online, social media, and consumer purchasing behavior. Dr. Bryant has presented her research at a variety of professional conferences including the Society for Marketing Advances, American Marketing Association, Marketing \& Public Policy, and the American Council on Consumer Interests. She has also been an invited speaker at the University of Alabama and the Rochester Institute of Technology. Prior to academia, Bryant's professional experience includes more than thirteen years in consumer market research and strategic decision analysis with several wellknown companies including Merck, Johnson \& Johnson, and Autotrader.com.

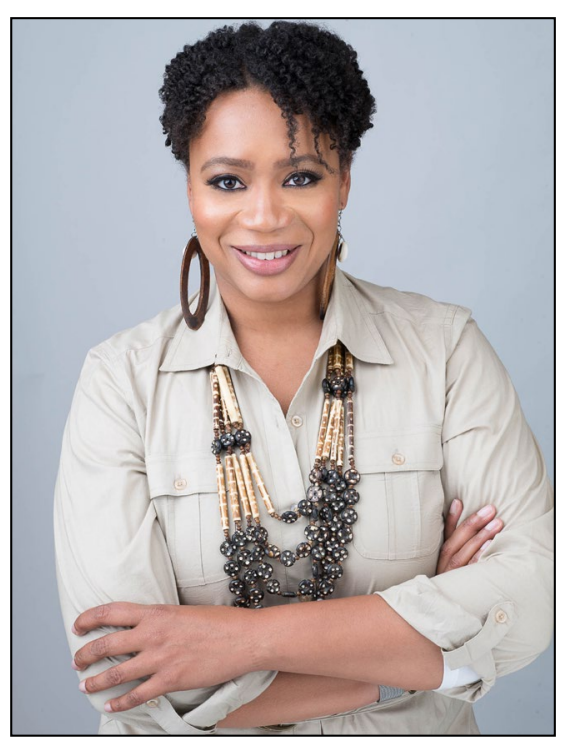






\section{PROCEEDINGS OF THE \\ 2019 INTERNATIONAL SUMMIT \\ OF THE \\ MUSIC \& ENTERTAINMENT \\ INDUSTRY EDUCATORS \\ ASSOCIATION}

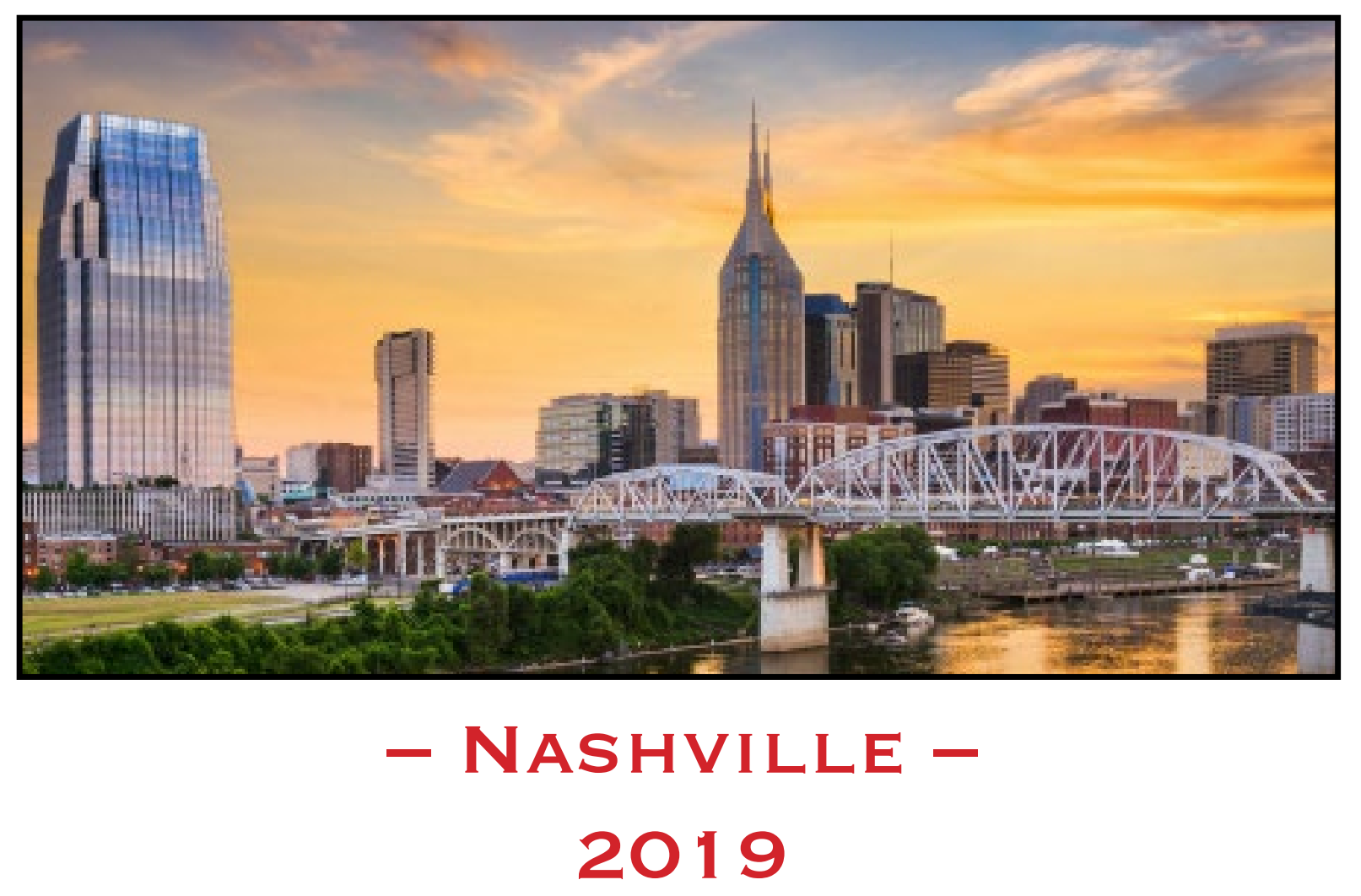

March 21 - 23, $2019 \cdot$ Belmont University - Nashville 